\title{
A Vascular-appearing Spindle Cell Xanthogranuloma in a Child
}

Daniel C. Morse ${ }^{1}$, Jaime A. Tschen ${ }^{2}$, Micheal R. Migden ${ }^{3}$, Sirunya Silapunt ${ }^{4}$

1. Mcgovern Medical School, University of Texas Mcgovern Medical School at Houston, Houston, USA 2. Dermpath, St Joseph Dermpath, Houston, USA 3. Departments of Dermatology and Head and Neck Surgery, The University of Texas Md Anderson Cancer Center, Houston, Texas 4. Dermatology, University of Texas Mcgovern Medical School at Houston, Houston, USA

Corresponding author: Sirunya Silapunt, sirunya.silapunt@uth.tmc.edu

\section{Abstract}

Spindle cell xanthogranuloma is a rare variant of juvenile xanthogranuloma that most commonly presents in adults as papulonodules. We describe a vascular-appearing case of spindle cell xanthogranuloma on the nose of a 10-year-old boy. The lesion was a dark red, well-demarcated, dome-shaped papule. Histopathology revealed spindle-shaped histiocytes in a storiform pattern that stained positive for cluster of differentiation 68 (CD68) and the nuclear antigen Ki-67. No vascular features were found. To our knowledge, this is the first reported spindle cell xanthogranuloma to mimic an angiomatous lesion.

Categories: Dermatology

Keywords: xanthogranuloma, pediatrics

\section{Introduction}

Juvenile xanthogranuloma (JXG) is a benign proliferative disorder of dermal histiocytes that typically presents as yellowish to reddish papulonodules [1]. Spindle cell xanthogranuloma (SCXG) is a rare form of JXG and most often occurs in adulthood. Here, we present a pediatric and vascular-appearing case of SCXG.

\section{Case Presentation}

A 10-year-old male patient presented with a 13-mm well-demarcated, dome-shaped, dark red nodule on the left ala (Figure 1). It had been present for eight months. During that time, it had increased in size and bled. The lesion received no prior treatment. The remainder of the physical exam was unremarkable.

Review began 04/23/2018 Review ended 05/05/2018 Published 05/08/2018

๑) Copyright 2018

Morse et al. This is an open access article distributed under the terms of the Creative Commons Attribution License CC-BY 3.0., which permits unrestricted use, distribution, and reproduction in any medium, provided the original author and source are credited.

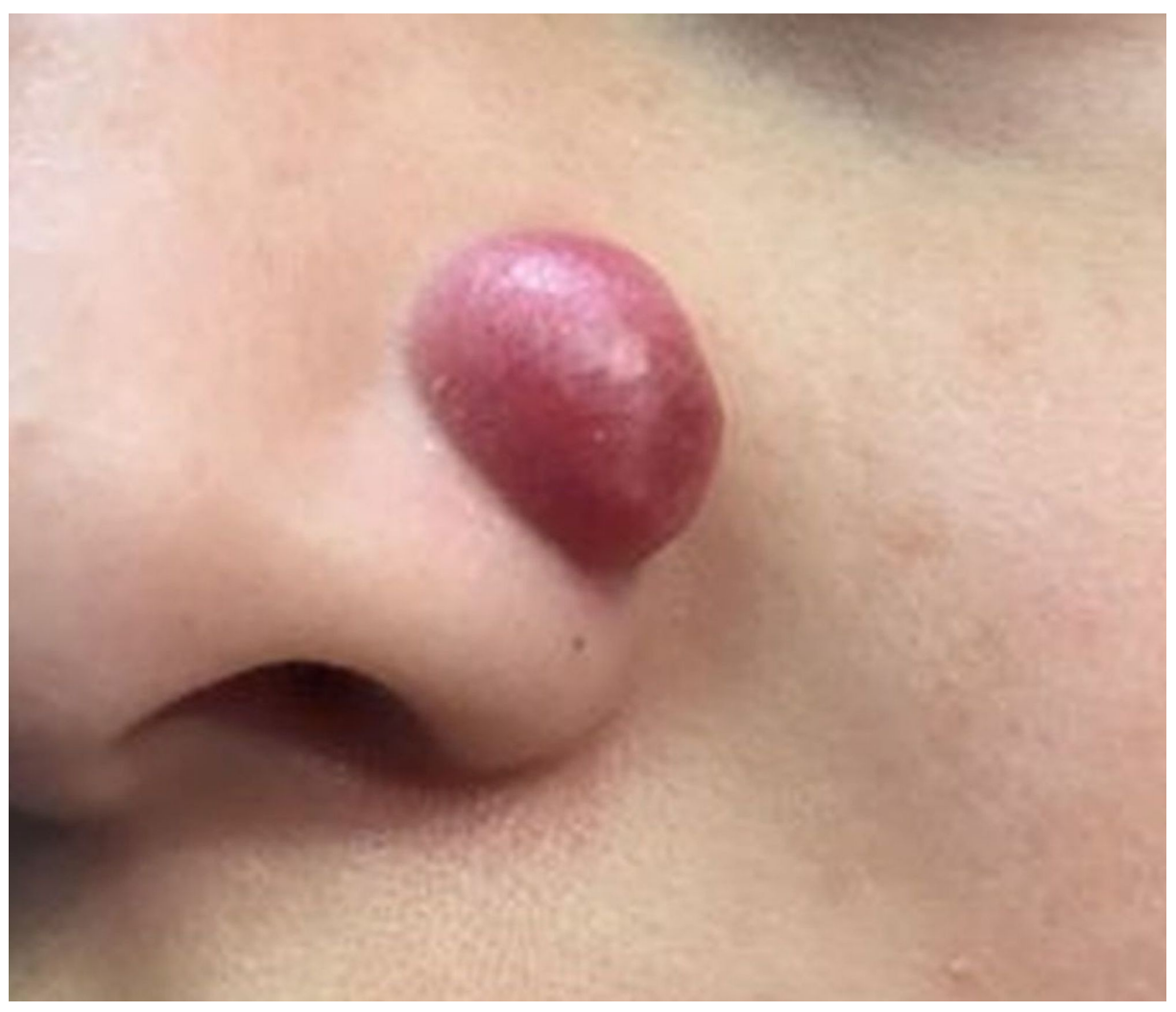




\section{Cureus}

FIGURE 1: A 13-mm well-demarcated, dome-shaped, dark red nodule on the left ala

A shave biopsy was performed, and histopathology revealed a diffuse infiltrate of spindle-shaped histiocytes in a storiform pattern (Figure 2), few multinucleated giant cells, scattered lymphocytes, and eosinophils (Figure 3). Immunohistochemical studies showed tumor cells positive for cluster of differentiation 68 (CD68) and the proliferation marker Ki-67 (Figure 4). The lesion was negative for S-100 protein, anti-melanoma antibody (HMB45), protein Melan-A, and smooth muscle actin (SMA). These histologic features supported the diagnosis of SCXG. The nodule resolved spontaneously several months later.

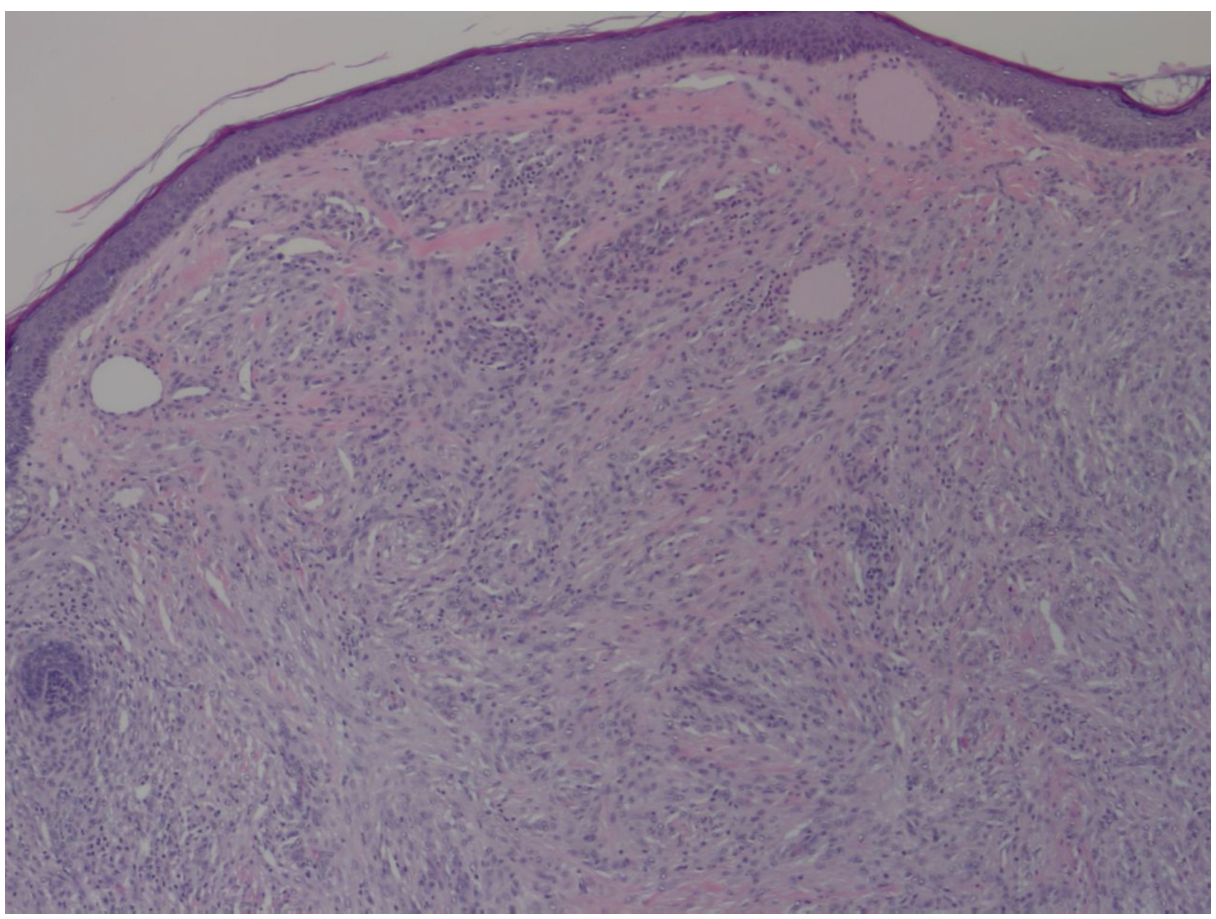

\section{FIGURE 2: Diffuse proliferation of spindle cells in a storiform pattern}

Hematoxylin-eosin stain, original magnification 200x

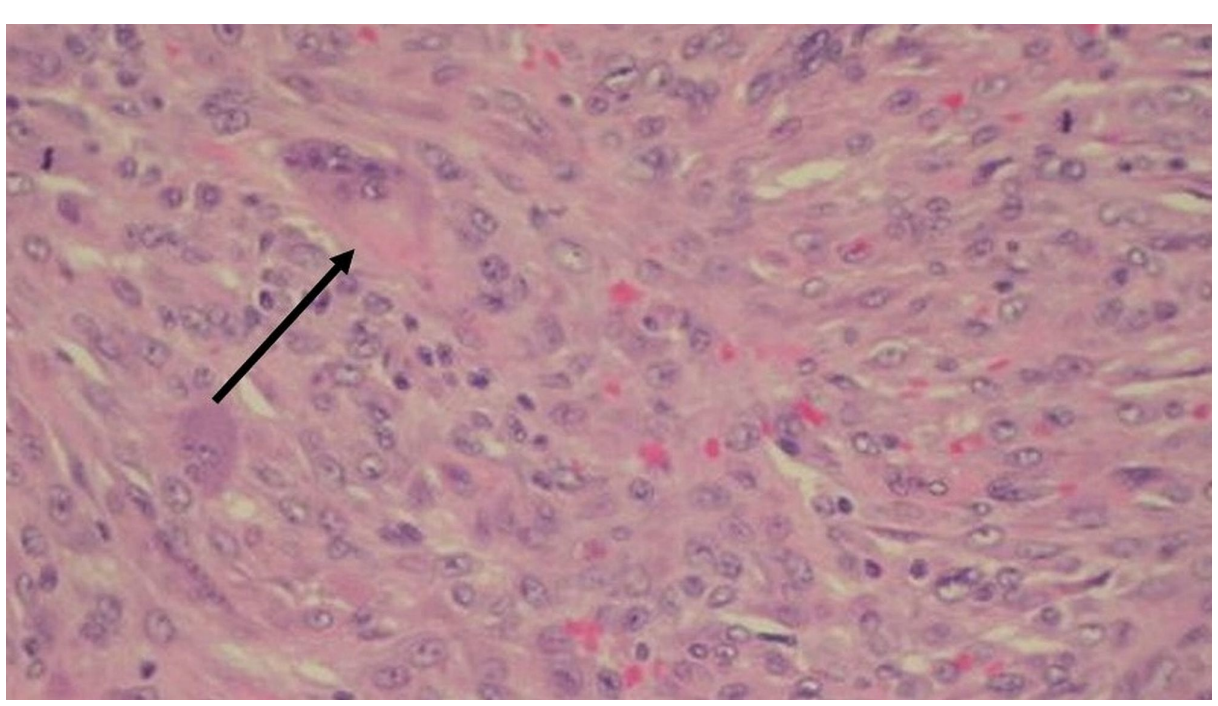

FIGURE 3: Dense proliferation of spindle-shaped histiocytes in the dermis, and a few multinucleated giant cells

Arrow pointing to multinucleated giant cells. Hematoxylin-eosin stain, original magnification 400x 


\section{Cureus}

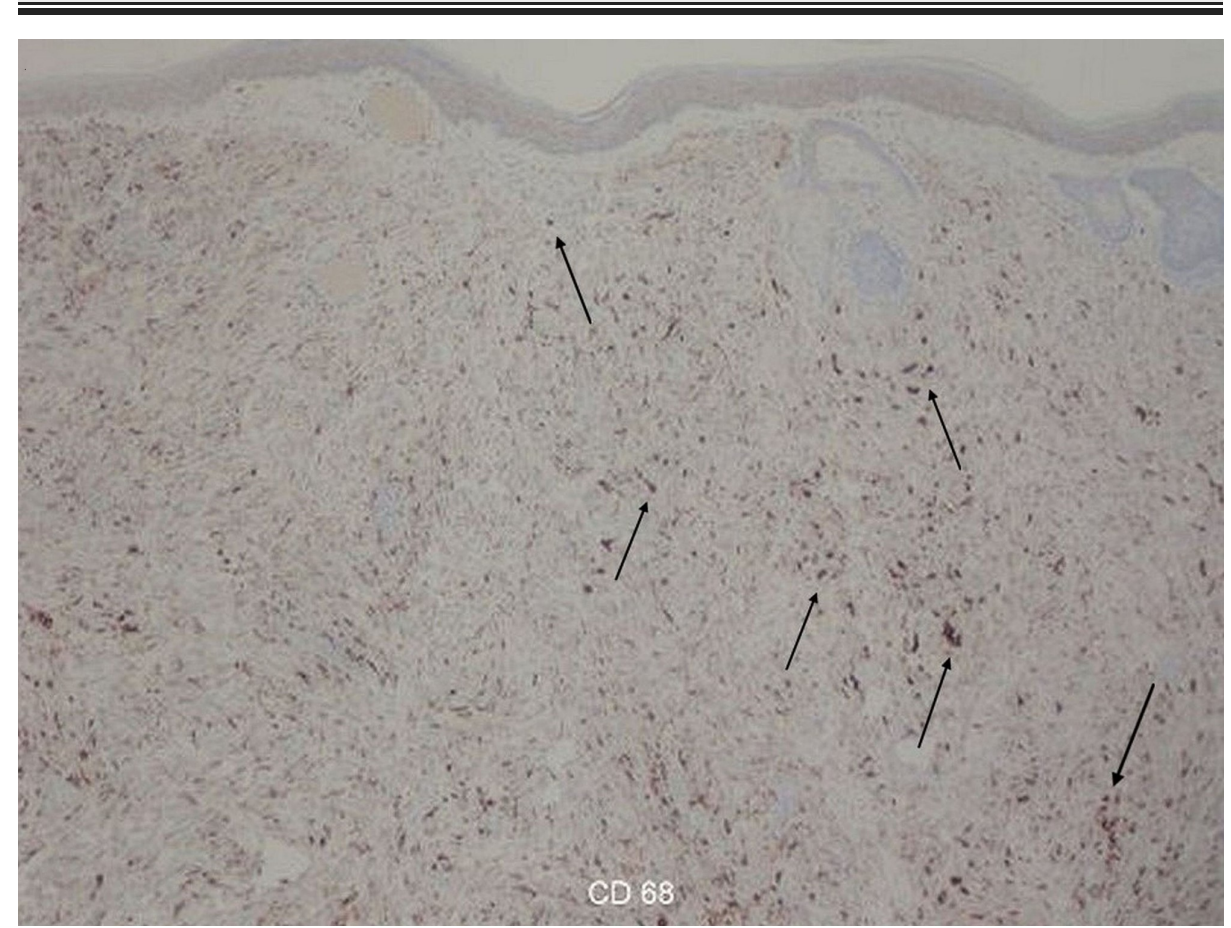

FIGURE 4: Diffuse infiltrate of spindle cells stained positive for CD68 (100x)

Arrows showing positive cluster of differentiation 68 (CD68) staining.

\section{Discussion}

SCXG is a rare variant of JXG, originally described in 1995 by Zelger et al. who reported 12 solitary cases of SCXG [2]. Since 1995, only a few reports of SCXG have been described [3-5]. A literature review of previous case reports, including our report, is summarized in Table 1 . SCXG classically presents as brownish to yellowish papulonodules involving the head, neck, upper trunk, and extremities in decreasing occurrence [2]. SCXG most often affects those between the ages of 20 - 40 years without preference for gender [2]. 


\section{Cureus}

\begin{tabular}{|c|c|c|c|c|c|c|c|}
\hline Case No. & Author, year & Age (years) & Gender & Location & Size $(\mathrm{mm})$ & Color & Recurrence \\
\hline 1 & Zelger BW et al., 1995 & 11 & $\mathrm{~F}$ & Chin & $\mathrm{n} / \mathrm{a}$ & $\mathrm{n} / \mathrm{a}$ & No \\
\hline 2 & Zelger BW et al., 1995 & 27 & $\mathrm{~F}$ & Neck & $\mathrm{n} / \mathrm{a}$ & $\mathrm{n} / \mathrm{a}$ & $\mathrm{n} / \mathrm{a}$ \\
\hline 3 & Zelger BW et al., 1995 & 21 & $\mathrm{M}$ & Occiput & $\mathrm{n} / \mathrm{a}$ & $\mathrm{n} / \mathrm{a}$ & No \\
\hline 4 & Zelger BW et al., 1995 & 59 & $\mathrm{M}$ & Back & $\mathrm{n} / \mathrm{a}$ & $\mathrm{n} / \mathrm{a}$ & No \\
\hline 5 & Zelger BW et al., 1995 & 18 & $\mathrm{~F}$ & Eyebrow & $\mathrm{n} / \mathrm{a}$ & $\mathrm{n} / \mathrm{a}$ & $\mathrm{n} / \mathrm{a}$ \\
\hline 6 & Zelger BW et al., 1995 & 31 & $\mathrm{~F}$ & Upper Trunk & $\mathrm{n} / \mathrm{a}$ & $n / a$ & No \\
\hline 7 & Zelger BW et al., 1995 & 38 & $\mathrm{~F}$ & Abdomen & $\mathrm{n} / \mathrm{a}$ & $\mathrm{n} / \mathrm{a}$ & No \\
\hline 8 & Zelger BW et al., 1995 & 41 & $\mathrm{M}$ & Neck & $\mathrm{n} / \mathrm{a}$ & $\mathrm{n} / \mathrm{a}$ & No \\
\hline 9 & Zelger BW et al., 1995 & 29 & $\mathrm{~F}$ & Back & $\mathrm{n} / \mathrm{a}$ & $\mathrm{n} / \mathrm{a}$ & No \\
\hline 10 & Zelger BW et al., 1995 & 24 & $\mathbf{M}$ & Calf & $\mathrm{n} / \mathrm{a}$ & $\mathrm{n} / \mathrm{a}$ & No \\
\hline 11 & Zelger BW et al., 1995 & 54 & $\mathrm{~F}$ & Thigh & $\mathrm{n} / \mathrm{a}$ & $\mathrm{n} / \mathrm{a}$ & $\mathrm{n} / \mathrm{a}$ \\
\hline 12 & Zelger BW et al., 1995 & 15 & $M$ & Lower Arm & $\mathrm{n} / \mathrm{a}$ & $\mathrm{n} / \mathrm{a}$ & No \\
\hline 13 & DeStafeno JJ et al., 2002 & 3 & $M$ & Eyelid & $7 \times 7$ & Yellowish Brown & $\mathrm{n} / \mathrm{a}$ \\
\hline 14 & Kim CR et al., 2012 & 0.92 (11 months) & $\mathrm{F}$ & Occiput & $\mathrm{n} / \mathrm{a}$ & Yellowish Brown & $\mathrm{n} / \mathrm{a}$ \\
\hline 15 & Nakamura Y et al., 2013 & 10 & $\mathrm{~F}$ & Нip & $10 \times 5$ & Dark Red & No \\
\hline 16 & Morse DC et al., 2018 & 10 & $\mathrm{M}$ & Nose & 13 & Dark Red & No \\
\hline
\end{tabular}

TABLE 1: Literature review of reported cases of SCXG

SCXG: spindle cell xanthogranuloma; n/a: not available

In contrast to the typical SCXG presentation of brownish to yellowish papules appearing in adulthood, we describe a pediatric case of SCXG that presented with dark red vascular features appearing similar to a hemangioma. The histopathology failed to reveal vascular features and confirmed the diagnosis of SCXG.

Spitz nevus (SN) was also high on our differential diagnosis since it also presents as a rapidly growing reddish nodule in children [6]. Nakamura et al. reported a case of SCXG in a 10-year-old, initially diagnosed as an SN due to the nodule's dark red to bluish clinical appearance and peripheral blue background with white streaks evident upon dermoscopy [5]. However, histologic features of SN were not seen in our case.

Histological examination of SCXG typically reveals Touton-type multinucleated giant cells and spindleshaped histocytes in a storiform pattern [2]. The macrophage and dendritic cell ancestry of SCXG is confirmed through immunohistochemistry as SCXG stains positive for histiocyte markers: mature macrophage marker monoclonal antibody (HAM-56), CD68, and Factor XIIIa [2-3]. SCXG is histologically similar to progressive nodular histiocytosis; both tumors display a predominance of spindle cells in a storiform arrangement and multinucleated giant cells [2, 4]. However, progressive nodular histiocytosis appears in a disseminated pattern in the elderly, which is markedly different from the presentation of SCXG $[2,4]$. Dermoscopy findings of SCXG appear as an orange-yellow structureless pattern with an erythematous border [7]. The tumors usually resolve spontaneously in six to 36 months [1].

\section{Conclusions}

SCXG is a rare form of JXG that may clinically masquerade as various other neoplasms, including angiomatous lesions and Spitz nevi.

\section{Additional Information}

\section{Disclosures}

Human subjects: Consent was obtained by all participants in this study. Conflicts of interest: In compliance with the ICMJE uniform disclosure form, all authors declare the following: Payment/services info: All authors have declared that no financial support was received from any organization for the 


\section{Cureus}

submitted work. Financial relationships: All authors have declared that they have no financial relationships at present or within the previous three years with any organizations that might have an interest in the submitted work. Other relationships: All authors have declared that there are no other relationships or activities that could appear to have influenced the submitted work.

\section{References}

1. Dehner LP: Juvenile xanthogranulomas in the first two decades of life: a clinicopathologic study of 174 cases with cutaneous and extracutaneous manifestations. Am J Surg Pathol. 2003, 27:579-93. 10.1097/00000478200305000-00003

2. Zelger BW, Staudacher C, Orchard G, et al.: Solitary and generalized variants of spindle cell xanthogranuloma (progressive nodular histiocytosis). Histopathology. 1995, 27:11-19. 10.1111/j.13652559.1995.tb00285.x

3. DeStafeno JJ, Carlson JA, Meyer DR: Solitary spindle-cell xanthogranuloma of the eyelid. Ophthalmology. 2002, 109:258-61. 10.1016/S0161-6420(01)00879-X

4. Kim CR, Kim HJ, Jung MY, et al.: A case of congenital spindle cell xanthogranuloma . Am J Dermatopathol. 2012, 34:672-73. 10.1097/DAD.0b013e3182327e40

5. Nakamura Y, Nakamura A, Muto M: Solitary spindle cell xanthogranuloma mimicking a spitz nevus . Am J Dermatopathol. 2013, 35:865-67. 10.1097/DAD.0b013e3182840d2d

6. Luo S, Sepehr A, Tsao H: Spitz nevi and other spitzoid lesions. Part I. background and diagnoses. J Am Acad Dermatol. 2011, 65:1073-84. 10.1016/j.jaad.2011.04.040

7. Palmer A, Bowling J: Dermoscopic appearance of juvenile xanthogranuloma. Dermatology. 2007, 215:25659. 10.1159/000106586 